\title{
Tensile Strength of Al Particles/Sisal Fibres Hybrid Composite with Epoxy Matrix
}

\section{Petr Valášek}

Faculty of Engineering, Czech University of Life Sciences Prague. Kamýcká 129, 165 21, Prague. Czech Republic. Email: valasekp@tf.czu.cz

The hybrid composite polymer system was prepared by a vacuum infusion. The reinforcement phase of the composite consists of natural fibers and inorganic aluminum particles. Hard inorganic particles are used in composite systems to optimize certain mechanical characteristics such as hardness, wear resistance or even strength. Hybrid system with an epoxy matrix and a variable concentration of reinforcing phases of aluminum min. purity of $99 \%$ (average particle size $31 \mu \mathrm{m}$ ) and sisal fibers was used in the experiment. Sisal fibers were used without a preferred orientation - it was a disordered long-fiber composite system and fibers were treated with $6 \%$ aqueous NaOH. The experiment focuses mainly on the hardness and strength characteristics of the composite. Electron microscopy was used to describe the particle morphology and size, and to evaluate matrix filler distribution and interphase interactions.

Keywords: Agave sisalana, Electron microscopy, Interaction, Mechanical characteristics

\section{Acknowledgement}

The results were supported by the grant IGA TF 2017 (31140/1312/3113).

\section{References}

[1] RUGGIERO, A., D'AMATO, R., GÓMEZ, E., MEROLA, M. (2016). Experimental comparison on tribological pairs UHMWPE/TIAL6V4 alloy, UHMWPE/AISI316L austenitic stainless and UHMWPE/AL2O3 ceramic, under dry and lubricated conditions. In: Tribology International, Vol. 96, pp. 349 - 360.

[2] MÜLlER, M., VALÁŠEK, P. (2012). Abrasive wear effect on Polyethylene, Polyamide 6 and polymeric particle composites. In: Manufacturing Technology, 12, pp. $55-59$.

[3] VALÁŠEK, P., MÜLLER, M. (2013). Polyurethane resins filled with inorganic waste particles. In: Manufacturing Technology, Vol. 13, No. 2, pp. $241-247$.

[4] RUGGIERO, A., VALÁŠEK, P., MÜLlER, M. (2016). Exploitation of waste date seeds of Phoenix dactylifera in form of polymeric particle biocomposite: Investigation on adhesion, cohesion and wear: In: Composites Part B: Eng, Vol. 104, pp. $9-16$.

[5] RUGGIERO, A., et al. (2015). Friction and wear behaviors of Al/Epoxy Composites during Reciprocating Sliding tests. In: Manufacturing Technology, Vol. 15, No. 4, pp. $684-689$.

[6] FOWLER, P.A., HUGHES, J.M.. ELIAS, R.M. (2006). Biocomposites: technology, environmental credentials and market forces. In: Journal of the Science of Food and Agriculture, Vol. 86 (2006), pp.1781 - 1789.

[7] MÜLLER, M. (2017). Analysis of production parameters of single-lap bonds adhesive bonded with composites based on aluminium filler. In: Research in Agricultural Engineering, Vol. 63, pp. 36 - 44.

[8] BOCKENHEIMER, C., VALESKE, B., POSSART, W. (2002). Network structure in epoxy aluminium bonds after mechanical treatment. In: International Journal of Adhesion and Adhesives, Vol. 22, pp. 349- 356.

[9] MÜllER, M. CIDLINA, J.,DĚDiČOVÁ, K.., KROFOVÁ, A. Mechanical properties of polymeric composite based on aluminium microparticles. In: Manufacturing technology, Vol. 15, pp. $624-628$.

[10] HE, D., et al. (2017). Multifunctional polymer composites reinforced by carbon nanotubes-Alumina hybrids with urchin-like structure. In: Materials Today Communications, Vol. 11, pp. 94- 102.

[11] ZHAI, L., LING, G., LI, J., WANG, Y. (2006). The effect of nanoparticles on the adhesion of epoxy adhesive. In: Materials Letters, Vol. 60, No. 25-26, pp. 3031 - 3033.

[12] VALÁŠEK, P., MÜLLER, M. (2012). Polymeric particle composites with filler saturated matrix. In: Manufacturing Technology, Vol. 12, No. 13, pp. $272-276$.

[13] MIECK, K..P., NECHWATAL, A., KNOBELSDORF, C. (1994). Potential applications of natural fibres in composite materials. In: Melliand Textilberichte, Vol. 75, No. 11, pp $892-898$. 
[14] DWIVEDI,S.P., SHARMA, S., MISHRA, R.K. (2017). Effects of waste eggshells and SiC addition in the synthesis of aluminum hybrid green metal matrix composite. In: Green Processing and Synthesis, Vol. 6, No. 1, pp. 113123.

[15] NOVÁK, M. (2012). Surfaces with high precision of roughness after grinding. In: Manufacturing Technology, 12 , pp. $66-70$.

[16] ŤAVODOÁ, M. (2013). The surface quality of materials after cutting by abrasive water jet evaluated by selected methods. In: Manufacturing Technology, Vol. 13, No. 2, pp. 236 - 241.

[17] VALÁŠEK, P., MÜLLER, M., ŠLEGER, V. (2017). Influence of Plasma Treatment on Mechanical Properties of Cellulose-based Fibres and Their Interfacial Interaction in Composite Systems. In: BioResources, Vol. 12, pp. $5449-5461$.

[18] BOOPALAN, M., UMAPATHY, M.J., JENYFER, P. (2012). A Comparative Study on the Mechanical Properties of Jute and Sisal Fiber Reinforced Polymer Composites. In: Silicon, pp. 145 - 149.

[19] VALÁŠEK, P. (2016) Short sisal fibers reinforced epoxy resins: tensile strength. In: Manufacturing Technology, Vol. 16, pp. $637-641$.

[20] MÜLLER, M, VALÁŠEK, P, RUGGIERO, A. (2016) Strength characteristics of untreated short-fibre composites from the plant ensete ventricosum. In: BioResources Vol. 1, pp. $255-269$.

[21] VALÁŠEK, P., RUGGIERO, A., MÜLLER, M. (2017). Experimental description of strength and tribological characteristic of EFB oil palm fibres/epoxy composites with technologically undemanding preparation. In: Composites Part B - Engineering, Vol. 122, pp. $79-88$.

[22] FÁVARO, S.L., ET. AL. (2010). Chemical, morphological and mechanical analysis of sisal fiber-reinforced recycled high-density polyethylene composites. In: Polymer Letters, Vol. 4, pp. 465- 473.

[23] KU, H., WONG, P. (2012). Contrast on tensile and flexural properties of glass powder reinforced epoxy composites: Pilot study. In: Journal of Applied Polymer Science, Vol. 123,pp. 152 - 161.

[24] SATAPATHY, B.K., BIJWE, J. (2002). Analysis of simultaneous influence of operating variables on abrasive wear of phenolic composites. In: Wear, Vol. 253,pp. $787-794$. 